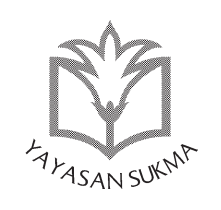

SUKMA: JURNAL PENDIDIKAN

ISSN: 2548-5105 (p), 2597-9590 (e)

Volume 2 Issue 2, Jul-Dec 2018, pp. 187-203

https://doi.org/10.32533/02202.2018

www.jurnalsukma.org

\title{
LEARNING GRAMMAR THROUGH PHYSICAL GAMES
}

\section{Sya'baningrum Prihhartini}

Universitas Islam '45 Bekasi, Indonesia

email: syabaningrum@englit45bekasi.org

\begin{abstract}
This study aims to investigate the language output resulted from physical games played as a practice to learn grammar. There were twenty university students involved in the game in which they had to jump and throw a marker towards cue cards that contained questions in If-Conditional Type II structure. The students' language output during the game was recorded and analyzed qualitatively. The result shows that physical game facilitates the learners to acquire new grammatical items and that it is effective to a good extent. [Tulisan ini bermaksud untuk menelisik bahasa dan kosakata yang muncul saat permainan fisik yang dipakai sebagai wahana pembelajaran tata bahasa
\end{abstract}


Inggris. Dalam penelitian ini, dua puluh orang mahasiswa dilibatkan dalam sebuah permainan fisik yang mengharuskan masing-masing peserta melakukan lompatan dengan satu kaki dan melemparkan alat penanda ke tempat kartu. Setiap kartu berisi pertanyaan dengan tema "If-Conditional Type II Structure". Setiap kata-kata yang muncul dari peserta dicatat dan dianalisis secara kualitatif. Hasil penelitian menunjukkan bahwa permainan fisik membantu pembelajar dalam memahami prinsip-prinsip tata bahasa Inggris.]

Keywords: physical games, grammar, accuracy

\section{A. Introduction}

Grammar appears and is taught in many different forms. In some textbooks, especially those normally used for General English programs like Touchstone (McCarthy, McCarten, and Sandiford 2004) or Life (Stephenson, Dummett, and Hughes 2014), grammar section appears as a small part to support the main language skills (listening, reading, speaking, and writing). Some other textbooks, which focus on compositions, like Writer's Choice Grammar and Composition (McGraw-Hill 2011), provide grammar with more extensive explanation and practices. The same as textbooks, grammar teaching varies depending on the degree of explicitness. Some teachers teach grammar explicitly while others do implicitly (Ellis 2014; Ellis et al. 2009; Nazari 2013). In Indonesia, where English is still considered as a foreign language, grammar holds a quite important role (Male 2011), especially for Junior High School and Senior High School students, since the high-stake English National Examination (Umam 2011; Sutari 2017) covers grammar-related questions. The high-stake test leads to negative washback effect, as English teachers are pushed to devote most of the teaching times for test preparations and strategies (Sukyadi and Mardiani 2011; Sutari 2017). Memorising grammar rules and practicing discrete grammati- 
cal structures (Margana and Widyantoro 2017; Sutari 2017) are mostly how the students learn grammar, which make no surprise that English grammar is then often perceived as "boring" and "difficult" (Prihhartini and Halimi 2016), "uninteresting and frustrating " (Tikkha 2014), and even "complicated and scary"(Paris and Yussof 2012). Attempts have been done to change this negative perception, and one of those attempts is achieved through games (Tuan and Doan 2010; Yolageldili and Arikan 2011; Baleghizadeh and Oladrostam 2011; Hamzah and Dourado 2010).

Using games to teach and learn grammar have been intensively promoted, especially with more studies reported positive findings (Khonmohammad, Gorjian, and Eskandari 2014; Sultanova 2011; Ashok, Revathi, and Saminathan 2013; Hamzah and Dourado 2010; Yolageldili and Arikan 2011; Baleghizadeh and Oladrostam 2011). Games are claimed to be effective means to help students acquire grammar rules as they are engaging (Wright, Betteridge, and Buckby 2006; Ashok, Revathi, and Saminathan 2013) and provide a relaxed atmosphere to learn (Yildiz and Senel 2017; Flores 2015). Games also expose the learners to a rich, meaningful, and comprehensible input (Krashen 1985) and repetition (Tomlinson and Masuhara 2009; Ardiansyah 2016), which allow the learners to internalize input. For that reason the current study seeks to investigate to what extent games help learners learn targeted grammatical item.

\section{Literature Review}

Grammar teaching and learning has long been perceived with words like "difficult" and "boring" (Brown 2014; Prihhartini and Halimi 2016), "uninteresting and frustrating" (Tikkha 2014), and even "complicated and scary" (Paris and Yussof 2012), which partly due to monotonous teaching techniques involving pattern memorization and working on written exercises (Marcellino 2008).

There has been a long debate whether grammar should be taught. At one end were those who believed that L2 acquisition 
happens in naturally and that grammar instruction will not help learners acquiring the language (Krashen 1981; Krashen 1985). In his Input Hypothesis, Krashen argued that what matter most for language acquisition are access to comprehensible input and the learners are sufficiently motivated. On the other end were those who argued that explicit knowledge the learners in the process of formulating messages as well as monitoring (Ellis 2006).

There has been a growing interest in the use of physical games in language learning in general and grammar learning in particular, which can be seen from numorous websites (see www.busyteachers.org; www.weareteachers.com; www.onestopenglish.com, for some ready-to-use games) providing game techniques and lesson plans, all ready to be utilized by teachers who might not have enough time designing their own games. However, despite the growing interests in using physical games or other types of kinesthetic activities in language classroom, it is very surprising that very few empirical studies can be found using the term "physical games". One that thoroughly reviewed past studies and related them with physical games and second language acquisition was written by Tomlinson and Masuhara (2009). In their paper, they laid out several principles that relate physical games with second language acquisition.

The first principle is that the learners need experience of the language being used in variety of different ways for a variety of purposes in order to acquire the ability to use the language effectively. Tomlinson and Masuhara (2009) also emphasized that frequent exposure is important for the learners to acquire particular language items. This point of the importance of repetition was also pointed out by Nation (2005). The second principle is that the learners need to be engaged both affectively and cognitively in the language experience so that the learners can maximize their exposure to language in use (Tomlinson and Masuhara 2009) . In relation to that point, games are highly motivating because they are amusing, interesting, and at the same time challenging (Tuan and Doan 2010). Especially for physical 
games since the games will likely ask the students to get out of their seats, the games will push them to activate their mental capasities and stimulate neutral networks, hence instigating the learners in learning and retention (Tuan and Doan 2010).

The third principle is that the learners need to achieve positive affect in order to achieve communicative competence (Tomlinson and Masuhara 2009). They need to feel positive about the target language, the enviroment, the teachers, and their peers. They also need to possess positive self-esteem, be emotionally involved in the learning process and need to feel successful. This is also pointed out by Arnold (2011) who states that "positive affect can provide invaluable support for learning just as negative affect can close down the mind and prevent learning from occuring altogether". The fourth principle is that L2 language learners can gain benefits from using mental processing that they normally use when acquiring and using their L1 (Tomlinson and Masuhara 2009). The fifth principle is that language learners can benefit from noticing (Schmidt 2001) salient features of language in use (Tomlinson and Masuhara 2009). In this case, it is a readiness for acquisition if they notice how a particular language item or feature is used. The last principle of language acquisition that can be achieved through physical games is that learners need opportunities to use language to try to achieve communicative outcomes (Tomlinson and Masuhara 2009). During the game, learners have opportunities to test their hypothesis and also gain feedback from teacher and peers.

Despite the scarcity of relevant works when it comes to physical games and grammar learning, some earlier studies (Bush 2015; Paris and Yussof 2012) have investigated different types of games and their effectiveness in language acquisition. Paris and Yusof (2012) studied on how to enhance grammar using board games. In their study, 115 students were put into four groups, and questionnaires as well as pretest and posttest were used as research instruments. The result showed beneficial effects of using board games in teaching grammar. Bush (2015) examined the impact of clssroom games on the acquisi- 
tion of second language grammar. Bush put 34 students into two groups, in which one group studied using games and another studied using the traditional teaching techniques. Pretest, immediate posttest, and delayed posttest were utilized to measure the performances, and t-test as well as mixed ANOVA were used. The findings showed no significant difference on both groups' performances, but the students were motivated by the games.

\section{Methodology}

This study was set in a naturalistic classroom where 20 university students were studying in a class. There were 7 male and 13 female students, and all students have been studying for around 11-12 years when the research was conducted.

The game was an adaptation of Hopscotch, or it's called Engklek in Indonesia. In this game, the players take turn throwing a marker towards some laid cue cards, jump on one leg towards the card where the marker lands, and answer the question written on the card. The students in this study were put in 3 groups, and each group was given a set of cue cards and a marker.

The questions written on the cue cards were all in If-Conditional Type 2 structure. Some questions were: 1) If you stepped on Mars for the first time, what would you do?, 2) How would people travel across Mars?, 3) How would you grow plants on Mars, 4) What kind of people would you find on Mars?

\section{B. Students' Engagement with the Game}

During the game the students were involved in a number of physical movements. Among others were : 1) throwing markers towards the cue cards, 2) jumping one leg towards the card where the marker landed,3) using gestures to help them clarify meaning, and 4) squating and standing while watching their friends and waiting for their turn.

The students also made a lot of noises like:1) clapping hands, 2) laughing when they heard their friends' answers, and 
when their friends couldn't hit the intended card, 3) shouting/ reacting to their friends' answers.

Those movements and noises display how they were emotionally and physically engaged to the game. This was one of the principles of language acquisition that Tomlinson and Masuhara (2009) emphasized, that " feeling enjoyment, pleasure, and happiness; feeling empathy; being amused; being excited; and being stimulated are most likely to influence acquisition positively, especially if the learner is experiencing positive affect in the sense of being confident, motivated, and willingly engaged". This also shows how positive affect (Arnold 2011) influence their learning as they get absorbed to learn in a stress-free environment.

\section{Repetition}

In this game, each group received a set of cue cards (7 cards) to be laid on the floor and a marker to throw towards the cards. All questions in the cards were in If-Conditional Type 2 form. Hence, each player in each group would likely get to play and answer the questions written in the cue cards using If-Conditional Type 2 up to seven times. As a result, they had to produced answers in similar way many times. This form of repetition is essential for language acquisition, as students "need to experience particular language items many times in meaningful and comprehensible input in order to eventually acquire them" (Tomlinson and Masuhara 2009).

\section{Noticing the Gap and Self-correction}

(Case \#1)

DT : and the second thing is ..I will..I would discover some place. And the last thing, build the technology.

(Case \#2)

WDO : If you stepped on Mars for the first time, what would you do? I will.. I would make some food, and...then 
make some video, and then.. spread it to internet.

In Case \# 1, students DT got a question of 3 things she would do to turn Mars a better place to live. At first she said "I will", but then she realized that she should have used the past modal verb instead, which led her to reformulate her sentence to become " $I$ would". Hence, DT could recognise her own mistake and repair it by herself. Similar case happened to WDO (Case \#2), who noticed he just used "will" instead of "would" and could reformulate the sentence by himself right away.

(Case \#3)

YG : As I said, aa.. I would like..I would.. I would bring.. potato, I mean food, water, and tent.

Similar structures can be confusing and lead a person to use one inaccurately. Student YG (Case \#3) was about to mention 3 things he would bring to Mars when he noticed he was using the incorrect "would" structure and did a self-repair to fix that mistake. At first he said "would like", which is a verb pattern related to polite offer or request. Then he caught on that mistake and repaired it by himself. He also repeated the correct verb (I would, I would bring) to confirm the right structure. Besides verb pattern, YG also clarified that he meant "food" when he mentioned "potato".

(Case \#4)

DY : I will bring cigarette, matches, and I will bring.. ya to.. to burn the smoke, the cigarette, and I will bring... I will bring my..my mobile phone.

Self-correction that was found during the game of this present study does not only involve verb pattern but also word choice. Student DY (Case \#3) was explaining three things he would bring to Mars when he recognised a mistake he just commited. He was giving a reason why he would bring matches to Mars when he said "to burn the smoke" instead of "light a cigarette". Even though he failed to correct "burn", he managed to detect a more accurate word choice in "cigarette" to replace 
"smoke". In this situation, the source of mistake related to word choice happened when he mentally translated the idea from L1 to L2 and chose "smoke" because it is usually a word to describe the activity (smoking) and "burn" because this is an activity of setting a fire on something.

From the four cases of noticing and self-correction above, it was shown how the game facilitated the learners to notice the gap between the structure/word that they produced and what they were supposed to say. This noticing (Schmidt 2001) led them to self-correct (Lyster 1998; Goo 2018) their utterance. Self-correction or self-repair, according to Lyster (1998), can be beneficial for L2 learning as attempts to self-correct provide opportunities to proceduralize target language knowledge already internalized in declarative form. Besides, when learners notice for themselves how a particular language item or feature is used, they are more likely to develop their language awareness and achieve readiness for acquisition (Tomlinson and Masuhara 2009).

\section{Clarification \& Elaboration}

(Case \#1 - the student misunderstood the question on the cue card)

FT : I would grow plant on Mars

T : (pointing at the cue card) "How? How? The way.."

FT : By throw..supplement like water..but pill.

In Case \#1, Student FT misunderstood the question at first, so the teacher clarified by asking how/the way people would grow plant on Mars. Responding to this question, FT replied that she would throw water supplement in a form of pill.

(Case \#2 - interlocutor couldn't hear the italic part because the situation was noisy)

WND : I will find alien to be my friend.

$\mathrm{T} \quad$ : You would find alien to what?

WND : To be my friend. 
Cases like \#2 happen when the surrounding is noisy and it is difficult to understand what a person is saying. In the situation above, the teacher gave a recast or implicit feedback (Ellis et al. 2009; Lyster 1998) by asking "you would find alien to what?" to do two jobs: 1) reminding WND to use modal verb would instead of will, and 2) getting the missing information. To that question, WND only managed to complete the missing information and answer "to be my friend".

(Case \#3 - the student couldn't find the right word)

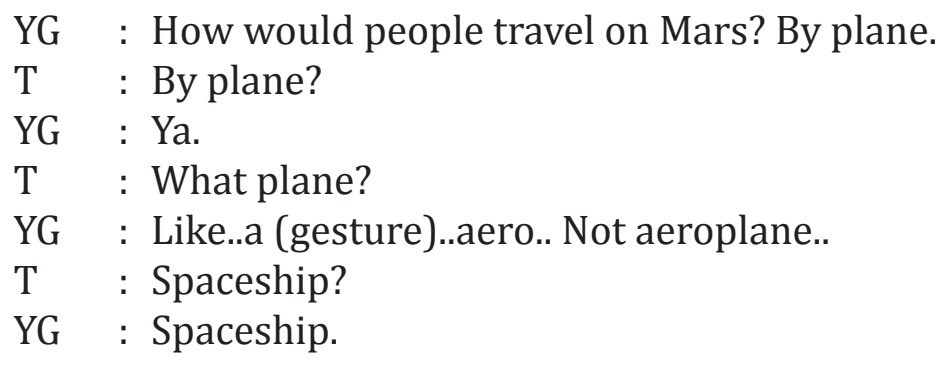

In Case \#3, student YG got a question on how people on Mars would travel, which he simply answered "by plane". The teacher wanted for a confirmation by asking" by plane?", and he confirmed that. The teacher tried to get YG elaborate his answer by asking what kind of plane, and YG attempted to describe a specific plane and used gestures to help him getting the message across, but he could not get the English name for that. The teacher aided him by eliciting a word "spaceship", which YG confirmed.

(Case \#3 - the student didn't understand the question)
MFT : (reading the cue card) Aaaa...... what does it mean, Miss?
T : How.. the way you grow plants on Mars.
MFT : I make it from the ..bibit apa Miss?
$\mathrm{T} \quad$ : Seed?
MFT : Seed.. from the seed.. I will grow it from the seed.
$\mathrm{T} \quad$ : Is it the same like on Earth? You think it would be the same like on Earth?

MFT : Aa.. no. 
T : Okay. So what makes it different?

MFT : Maybe..hmm..with.. some.. technology. Some technology.

T : Some technology. Okay.

In Case \#3, MFT didn't understand the question written on the cue card, so she asked for explanation from the teacher. She later experienced another problem when she didn't know what the English name for an L1 word (bibit), so she asked for a help from the teacher. After listening to MFT's answer (I will grow it from the seed), the teacher wanted her to elaborate her answer, so the teacher elicitated with questions (you think it would be the same like on Earth? What makes it different?), which were uptaken by MFT (with some technology).

(Case \#4 - the student had to explain concept)

DY : (holding the card "What kind of people would you find on Mars?) Ya.. people with.. alien.

$\mathrm{T} \quad$ : What kind of alien? What kind of alien?

DY : Hybrid. Hybrid.

The case is same with Case \#4. DY only gave a short answer (people with alien), so the teacher asked for an elaboration on that by asking "what kind of alien?". The question brought DY to think of a certain type of alien and answered "Hybrid".

From the cases shown above, it can be seen that during the game some of the learners met certain conditions, such as misunderstanding, not being clear, or having difficulty in explaining concept. Such conditions then led the interlocutor, in this case the teacher, to request for clarification and/or elaboration. When the students need to clarify and/or elaborate things, they are pushed to utilise whatever means that they can use, such as using gestures and thinking fast to find the right words, and also eliciting ideas to get help from their interlocutor. Thus, successful feedback happen as the students react to the teacher's elicitation/ recast (Sheen and Ellis 2011). This condition reflects what Tomlinson and Masuhara (2009) have explained as one of the principles of 
language acquisition that can be achieved through games, that is the students are pushed to clarify and elaborate (Swain 2005) and get to elicit meaningful and comprehensible input from their interlocutors (Tomlinson and Masuhara 2009).

\section{Conclusion}

As the findings show, physical game that was applied in this study was effective in helping the students acquiring new grammatical item to a good extent, as the game facilitated the students to notice mistake and reformulate their utterance, clarify and elaborate ideas, and keep them motivated and engaged. Hence, it is suggested that language teachers start to incorporate physical games into lesson plans as a way of teaching and learning, and not just using it as filler. Well-designed games not only can help the students stay motivated, positive, and engaged, but they can also provide plentiful opportunities to enhance language skills and acquire new linguistic item. 


\section{BIBLIOGRAPHY}

Ardiansyah, Welly. 2017. "The Games-Based Grammar to Young Learners: A Case Study of English Teachers' Attitude on Teaching and Learning Process in the Classroom." Tarbawy: Jurnal Pendidikan Islam 1 (2). http://ojs.stainbabel.ac.id/ index.php/Tarbawy/article/view/74.

Arnold, Jane. 2011. "Attention to Affect in Language Learning." Anglistik: International Journal of English Studies 22 (1): 11-22.

Ashok, M. Leonard, P.S. Revathi, and P.B. Saminathan. 2013. "Effectiveness of Language Games in Learning English Grammar." Shanlax International Journal of Education 1 (3): 16-23. http://www.shanlaxjournals.in/pdf/EDN/V1N3/ EDN_V1_N3_002.pdf.

Baleghizadeh, Sasan, and Elnaz Oladrostam. 2011. "Teaching Grammar for Active Use: An Exploration of Three Instructional Techniques." LiBRI: Linguistic and Literary Broad Research and Innovation 2 (1): 70-78. https://www.edusoft.ro/brain/ index.php/libri/article/view/206.

Brown, Jessica. 2014. "Why Grammar Isn't Cool - and Why That May Be about to Change | Mind Your Language." The Guardian, March 21, 2014, sec. Media. https://www.theguardian.com/ media/mind-your-language/2014/mar/21/mind-yourlanguage-cool-grammar.

Bush, Jerome C. 2015. "The Impact of Classroom Games on the Acquisition of Second Language Grammar." Language in Focus 1 (2): 17-29. https://doi.org/10.1515/lifijsal-2015-0007.

Ellis, Rod. 2006. "Current Issues in the Teaching of Grammar: An SLA Perspective." TESOL Quarterly 40 (1): 83-107. https:// doi.org/10.2307/40264512.

Ellis, Rod. 2014. "Grammar Teaching for Language Learning." Babylonia 02 (14): 10-15. http://babylonia.ch/fileadmin/ user_upload/documents/2014-2/Ellis.pdf.

Ellis, R., Shawn Loewen, Catherine Elder, Rosemary Erlam, 
Jenefer Philp, and Hayo Reinders. 2009. Implicit and Explicit Knowledge in Second Language Learning, Testing and Teaching. Second Language Acquisition. Multilingual Matters.

Flores, JFF. 2015. “Using Gamification to Enhance Second Language Learning." Digital Education Review 27: 32-54. http://revistes. ub.edu/index.php/der/article/view/11912.

Goo, Jaemyung. 2018. "Self-Correction." In The TESOL Encyclopedia of English Language Teaching, edited by J.I Liontas, 1st ed., 1-6. John Wiley \& Sons, Inc. https://doi. org/10.1002/9781118784235.eelt0099.

Khonmohammad, Hajar, Bahman Gorjian, and Zivar Eskandari. 2014. “Using Games to Affect Learners' Motivation in Learning English Grammar." International Journal of Language Learning and Applied Linguistics World 5 (March): 324-41.

Krashen, Stephen D. 1981. Second Language Acquisition and Second Language Learning. Pidginization and Creolization as Language Acquisition. https://doi.org/10.1111/j.14679922.2009.00554.x.

Krashen, Stephen. 1985. The Input Hypothesis. Issues and Implications. Longman.

Li, Jingguang. 2011. "The Literature Review about the Research on Learning Style Both Abroad and at Home." Theory and Practice in Language Studies 1 (12): 1780-85. https://doi. org/10.4304/tpls.1.12.1780-1785.

Lyster, Roy. 1998. "Negotiation of Form , Recasts , and Explicit Correction in Relation to Error Types and Learner Repair in Immersion Classrooms." Language 48 (2): 183-218.

Male, Hendrikus. 2011. "Students ' View on Grammar Teaching." Journal of English Teaching 1 (1): 57-69.

Marcellino, M. 2008. "English Language Teaching in Indonesia: A Continuous Challenge in Education and Cultural Diversity." TEFLIN Journal: A Publication on the Teaching and Learning of English 19 (1): 57-69. https://doi.org/10.15639/ TEFLINJOURNAL.V19I1/57-69. 
Margana, Margana, and Agus Widyantoro. 2017. “Developing English Textbooks Oriented to Higher Order Thinking Skills for Students of Vocational High Schools in Yogyakarta." Journal of Language Teaching and Research 8 (1): 26. https://doi. org/10.17507/jltr.0801.04.

McCarthy, Michael, Jeanne McCarten, and Helen Sandiford. 2004. Student Book Touchstone. Cambridge University Press.

McGraw-Hill. 2011. Writer's Choice Grammar and Composition Grade 9. College Composition and Communication. Vol. 16. The McGraw-Hill Company. https://doi.org/10.2307/355748.

Nazari, Nastaran. 2013. "The Effect of Implicit and Explicit Grammar Instruction on Learners' Achievements in Receptive and Productive Modes." Procedia: Social and Behavioral Sciences 70: 156-62. https://doi.org/10.1016/j.sbspro.2013.01.051.

Paris, T.N.S, and Rahmah Lob Yussof. 2012. "Enhancing Grammar Using Board Game." Procedia: Social and Behavioral Sciences 68 (August 2014): 213-21. https://doi.org/10.1016/j. sbspro.2012.12.221.

Prihhartini, S., and S.S. Halimi. 2016. "The Effect of Task Repetition and Focused Feedback on Students' Accuracy: A Case Study of Indonesian EFL Learners." In The 4th International Conference on Language, Literature, Culture And Education ( ICLLCE), edited by L.A Wahid, F.F.M Ali, S. Ismail, and M.I.A Wahab, 13-21. Infobase Creation Sdn Bhd.

Sheen, Younghee, and Rod Ellis. 2011. "Corrective Feedback in Language Teaching." In Handbook of Research in Second Language Teaching and Learning, edited by Eli Hinkel, 2nd ed., 593-610. Routledge.

Stephenson, Helen, Paul Dummett, and John Hughes. 2014. Life Beginner. Cencage Learning.

Sukyadi, Didi, and Ridha Mardiani. 2011. "The Washback Effect of the English National Examination (ENE) on English Teachers' Classroom Teaching and Students' Learning." K@ta 13 (1): 96-111. https://doi.org/10.9744/kata.13.1.96-111. 
Sultanova, D T. 2011. "The Use of Games in Learning English Grammar" in Proceeding of Uzbek-Indonesian Joint International Conference Gunadarma University - Jakarta 1 (October): 978-79.

Sutari, Velentina Rizki. 2017. "National Examination in Indonesia and Its Backwash Effects : Teachers' Perspectives." Advances in Social Science, Education and Humanities Research (ASSEHR) 82 (Conaplin 9): 331-33.

Swain, M. 2005. "The Output Hypothesis: Theory and Research." In Handbook of Research in Second Language Teaching and Learning, edited by Eli Hinkel, 471-84. Mahwah, NJ: Lawrence Erlbaum.

Tikkha, Neelam. 2014. "Teaching Grammar through Virtual Model, Kinesthetic Activities and Folklore." In Grammar and Grammar Teaching: Changing Perspectives, edited by Vathana Fenn, 2:205-12. www.languageinindia.com/april2014/ neelamgamesfinal.pdf\%0A\%0A.

Tomlinson, Brian, and Hitomi Masuhara. 2009. "Playing to Learn: A Review of Physical Games in Second Language Acquisition." Simulation \& Gaming 40 (5): 645-68. https:// doi.org/10.1177/1046878109339969.

Tuan, Luu Trong, and Nguyen Thi Minh Doan. 2010. "Teaching English Grammar Through Games." Studies in Literature and Language 1 (7): 61-75. https://doi.org/10.3968/n.

Umam, Chotibul. 2011. "National Examination of English in Indonesia: A Validity and Reliability-Based Elucidation." Jurnal Universum 5 (1): 1-14.

Wright, Andrew, David Betteridge, and Michael Buckby. 2006. Games for Language Learning. 3rd ed. Cambridge Handbooks for Language Teachers. Cambridge: Cambridge University Press. doi:10.1017/CB09780511667145.

Yildiz, Mustafa, and Mufit Senel. 2017. "Teaching Grammar through Task-Based Language Teaching to Young EFL Learners." The Reading Matrix: An International Online Journal 17 (2). http:// 
www.readingmatrix.com/files/17-a267g7f3.pdf.

Arıkan, Gülin Yolageldili and Arda. 2011. "Effectiveness of Using Games in Teaching Grammar to Young Learners." Elementary Education Online 10 (1). http://ilkogretim-online.org.tr/ index.php/io/article/view/1668. 